\title{
Kompetensi Pengadilan Tata Usaha Negara dalam Menyelesaikan Kasus Tanah tentang Hak Pengelolaan
}

\section{Competence of State Administrative Court in Completing Land Case on Right of Management}

\author{
Rafiqi $^{*}$ \\ Fakultas Hukum, Universitas Medan Area
}

\begin{abstract}
Abstrak
Hukum Eksekusi di PTUN berbeda dengan hukum eksekusi di peradilan perdata. Diperadilan perdata hukum eksekusi dilengkapi dengan sarana-sarana fisik, yaitu: Juru Sita, bantuan Alat Negara (Polisi) dan sebagainya, yang dapat memaksa secara fiksi agar pihak yang kalah mematuhi putusan pengadilan. Di PTUN hal itu tidak dimungkinkan, PTUN hanya dilengkapi sarana-sarana administrasi saja, sesuai dengan kewenangannya yang hanya mengadili dari segi legalitas administrasi (pengadilan administrasi). Hak Pengelolaan diterbitkan surat tanda bukti hak berupa sertipikat Hak Pengelolaan oleh Kantor Pertanahan.Hak pengelolaan merupakan hak atas tanah. Tujuan akan kepastian hukum itu sendiri akan dapat terpenuhi bila bila suatu perangkat atau sistem hukum itu dapat berjalan dan mendukung tercapainya suatu kepastia hukum, khususnya peranan lembagalembaga yang diberi wewenang

Kata Kunci: Peradilan Tata Usaha Negara, Kasus Tanah, Hak Pengelolaan
\end{abstract}

\begin{abstract}
The Law of Execution in the Administrative Court is different from the law of execution in civil courts. The civil trial of execution law is supplemented by physical means, namely: Jita Sita, aid of State Instruments (Police) and so on, which can force fiction so that the losers obey the court's decision. In the Administrative Court it is not possible, the Administrative Court is only equipped with administrative facilities only, in accordance with its authority which only judges in terms of administrative legality (administrative court). Rights Management issued a letter of proof of rights in the form of a certificate of Right of Management by the Land Office. The management rights are the right to land. The purpose of legal certainty itself will be fulfilled if if a device or legal system that can run and support the achievement of a legal kepolisia, especially the role of institutions that are authorized

Keywords: State Administrative Court, Land Case, Right of Management
\end{abstract}

How to Cite: Rafiqi, (2017). Kompetensi Pengadilan Tata Usaha Negara dalam Menyelesaikan Kasus Tanah tentang Hak Pengelolaan. JPPUMA: Jurnal Ilmu Pemerintahan dan Sosial Politik UMA, 5 (2): 108115

*Corresponding author: p-ISSN: 25491660

E-mail: rafiqi@staff.uma.ac.id

e-ISSN: 2550-1305 


\section{PENDAHULUAN}

Pada 24 September 1960 disahkan Undang-undang Nomor 5 tahun 1960 tentang Peraturan Dasar Pokok-pokok Agraria, Lembaran Negara Republik Indonesia (LNRI) tahun 1960 Nomor 104 Tambahan Lembaran Negara Republik Indonesia (TLNRI) Nomor 2043. Undangundang ini lebih dikenal dengan sebutan Undang-undang Pokok Agraria (UUPA). Undang-undang Pokok Agraria mempunyai arti sangat penting dalam pembangunan Hukum tanah di Indonesia, karena dengan diundangkannya Undangundang Pokok Agraria berlakulah hukum nasional dan tidak berlaku lagi Hukum tanah kolonial. Undang-undang pokok Agraria secara tegas mencabut atau menyatakan tidak berlaku lagi Agrarische Wet Stb 1870 Nomor 55 Agrarische Besluit Stb 1870 Nomor 118.

Selain hak-hak atas tanah sebagaimana disebutkan dalam Pasal 16 ayat (1) Undang-undang Pokok Agraria Nomor 5 Tahun 1960 dan Pasal 53 Undangundang Pokok Agraria terdapat hak penguasaan atas tanah, yaitu Hak Pengelolaan (HPL). Hak Pengelolaan adalah suatu hak atas tanah yang sama sekali tidak ada istilahnya dalam Undangundang Pokok Agraria dan khusus hak ini demikian pula luasannya terdapat diluar ketentuan dari Undang-undang Pokok Agraria (Parlindungan, 1989: 1). Selanjutnya dikatakannya bahwa istilah "Hak Pengelolaan diambil dari bahasa Belanda, yaitu beheersrecht, yang diterjemahkan menjadi Hak penguasaan".

Tanda bukti pendaftaran Hak Pengelolaan diterbitkan surat tanda bukti hak berupa Sertifikat Hak Pengelolaan oleh Kantor Pertanahan Kabupaten/Kota (dahulu Kantor Pendaftaran tanah). Sebagai implementasi dari peraturanperaturan mengenai Hak Pengelolaan sebagaimana Peraturan Pemerintah Nomor 8 Tahun 1953 jo Penanaman Modal Asing Nomor 9 tahun 1965 jo Penanaman Modal Nomor 1 Tahun 1966 diterbitkanlah Keputusan Bersama Menteri Dalam Negeri dan Menteri Perhubungan tentang
Penyediaan dan Penggunaan Tanah untuk keperluan Pelabuhan Nomor 191 Tahun 1969/SK.83/o/1969 tertanggal 27 Desember 1969 (Parlindungan, 1989: 14).

Salah satu tujuan pentingnya penyelesaian suatu sengketa adalah untuk memperoleh jaminan adanya kepastian hukum bagi seluruh pihak yang terlibat dalam suatu persengketaan. Tujuan akan kepastian hukum itu sendiri akan dapat terpenuhi bila bila suatu perangkat atau sistem hukum itu dapat berjalan dan mendukung tercapainya suatu kepastia hukum, khususnya peranan lembagalembaga yang diberi wewenang (Syarief, 2012: 371).

\section{PEMBAHASAN}

Konsep Hak Pengelolaan diperkenalkan oleh Peraturan Pemerintah Nomor 8 Tahun 1953. Peraturan Pemerintah Nomor 8 Tahun 1953 mengatur penguasaan tanah-tanah Negara oleh Kementerian, jawatan atau daerahdaerah swantantra. Hak Pengelolaan melalui konversi yang diatur dalam "Pasal 2 Peraturan Menteri Agraria Nomor 9 Tahun 1965 telah lahir jenis hak penguasaan atas tanah yang baru, yaitu Hak Pengelolan." (Santoso, 2012: 169).

Dalam Undang-undang Pokok Agraria Nomor 1 Tahun 196o dimuat hak penguasaan atas tanah tersebut terdapat hak menguasai negara atas tanah dan hak atas tanah. Hak Pengelolaan dalam Hukum Tanah Nasional terdapat perbedaan pendapat dikalangan para ahli. Ada yang menyatakan bahwa Hak Pengelolaan merupakan hak menguasi negara atas tanah dan ada pula yang berpendapat bahwa Hak Pengelolaan merupakan hak atas tanah.

A.P. Parlindungan menyatakan bahwa istilah "Hak Pengelolaan dari bahasa Belanda Beheerrecht, yang diterjemahkan menjadi Hak Penguasaan" (Santoso, 2012: 169). Hak Pengelolaan telah ada sebelum berlakunya Undang-undang Pokok Agraria Nomor 5 Tahun 1960 yang dikenal dengan Hak Penguasaan Atas 
Tanah Negara yang diatur oleh Peraturan Pemerintah Nomor 8 tahun 1953.

Hak Penguasaan Atas Tanah Negara ini kemudian oleh Peraturan Menteri Agraria Nomor 9 Tahun 1965 Tentang Pelaksanaan Konversi Hak Penguasaan Atas Tanah Negara dan Ketentuanketentuan Tentang Kebijaksanaan Selanjutnya tentang Pelaksanaan Konversi Hak Penguasaan Atas Tanah Negara dan kebijaksanaan, dikonversi menjadi Hak Pengelolaan (Zein, 1995: 24).

Dalam perkembangannya, Pasal 9 Peraturan Pemerintah Nomor 24 Tahun 1997 tentang Pendaftaran Tanah, Lembaran Negara Republik Indonesia (LNRI) Tahun 1997 Nomor 50 Tambahan Lemabaran Republik Indonesia Nomor 3696 bahwa Hak Pengelolaan termasuk objek pendaftaran tanah, selain Hak Milik, Hak Guna Usaha, Hak Guna Banguanan, Hak Pakai, tanah Wakaf, hak Milik Atas Satuan Rumah Susun, Hak Tanggungan dan Tanah Negara (Zein, 1995: 6).

Tanda bukti pendaftaran Hak Pengelolaan diterbitkan surat tanda bukti hak berupa sertipikat Hak Pengelolaan oleh Kantor Pertanahan. Menurut Pasal 1 angka 20 Peraturan Pemerintah Nomor 24 tahun 1997, yang dimaksud sertipikat adalah surat tanda bukti (Peraturan Pemerintah Nomor 24 Tahun 1997 Tentang Pendaftaran Tanah).

PTUN adalah singkatan dari Pengadilan Tata Usaha Negara, yang didalam Undang-undang Nomor 5 Tahun 1986 jo Undang-undang Nomor 9 Tahun 2004 jo Undang-undang Nomor 51 Tahun 2009 disebut juga Administrasi Negara. Undang-undang tentang Peradilan Tata Usaha Negara, Undang-undang Nomor 5 Tahun 1986 jo Undang-undang Nomor 9 Tahun 2004 jo Undang-undang Nomor 51 Tahun 2009.

PTUN secara resmi terbentuk dan dijalankan sejak tanggal 14 Januari 1991 Keputusan Presiden Republik Indonesia Nomor 52 Tahun 1996 tentang Pembentukan Pengadilan Tata Usaha Negara di Jakarta, Medan, Palembang, Surabaya dan Ujung Pandang (Keputusan
Presiden tentang Pembentukan PTUN di Jakarta,Medan,Palembang,Surabaya dan Ujung Pandang). Pasal 4 Undang-undang Peradilan Tata Usaha Negara Nomor 5 Tahun 1986 jo Undang-undang Nomor 9 Tahun 2004 jo Undang-undang Nomor 51 Tahun 2009 jo Undang Nomor 9 Tahun 2004 jo Undang-undang Nomor 51 Tahun 2009 menyebutkan "Peradilan Tata Usaha Negara adalah salah satu pelaku kekuasaan kehakiman bagi rakyat pencari keadilan terhadap sengketa Tata Usaha Negara." (Undang-undang Peradilan Tata Usaha Negara Nomor 5 Tahun 1986 jo Undang-undang Nomor 9 Tahun 2004 jo Undang-undang Nomor 51 Tahun 2009 jo Undang-undang Nomor 9 Tahun 2004 jo Undang-undang Nomor 51 Tahun 2009).

Sengketa Tata Usaha Negara dapat diketahui dengan menentukan apa yang menjadi tolak ukur sengketa Tata Usaha Negara. Tolak ukur Tata Usaha Negara (administrasi) adalah tolok ukur subyek dan pangkal sengketa. Tolak ukur subyek adalah (para) pihak yang bersengketa dibidang hukum administrasi negara (Tata Usaha Negara). Sedangkan tolok ukur pangkal sengketa administrasi yang diakibatkan oleh ketetapan sebagai hasil perbuatan administrasi Negara (Sjachran, 1992: 63).

Dengan demikian sengketa intern adalah menyangkut persoalan kewenangan pejabat Tata Usaha Negara yang disengketakan dalam satu departemen (instansi) atau kewenangan suatu departemen (instansi) terhadap departemen (instansi) lainnya, yang disebabkan tumpang tindihnya kewenangan, sehingga menimbulkan kekaburan kewenangan. (Setiadi, Persada, 1994: 93).

Ketentuan Pasal 1 ayat 10 Undangundang Peradilan Tata Usaha Negara Nomor 5 Tahun 1986 jo Undang-undang Nomor 9 Tahun 2004 jo Undang-undang Nomor 51 Tahun 2009 jo Undang-undang Nomor 9 Tahun 2004 jo Undang-undang nomor 51 Tahun 2009 tentang yang menyebutkan sebagai berikut: Sengketa Tata Usaha Negara adalah sengketa yang 
timbul dalam bidang Tata Usaha Negara antara orang atau badan hukum perdata dengan badan atau pejabat Tata Usaha Negara baik dipusat maupun didaerah, akibat dikeluarkannya Keputusan Tata usaha Negara termasuk sengketa kepegawaian berdasarkan peraturan perundang-undangan yang berlaku (Undang-undang Peradilan Tata Usaha Negara Nomor 8 Tahun 1986 jo Undangundang Nomor 9 Tahun 2004 jo Undangundang Nomor 51 Tahun 2009).

Pada dasarnya penggugat mengajukan suatu gugatan kepengadilan adalah bertujuan agar pengadilan melalui hakim dapat menyelesaikan perkaranya dengan mengambil suatu putusan. Bagi hakim dalam menyelesaikan suatu perkara yang penting bukanlah hukumnya, karena hakim dianggap tahu hukumnya (ius curia novit), tetapi mengetahui secara obyektif fakta atau peristiwa sebagai duduk perkara yang sebenarnya sebagai dasar putusannya, bukan secara langsung menemukan hukumnya tanpa perlu mengetahui terlebih dahulu duduk perkara sebenarnya (Harahap, 1997: 137).

Fakta atau peristiwa sebagai duduk perkara akan dapat diketahui hakim dari alat-alat bukti yang diajukan oleh para pihak yang bersengketa. Setelah dianggap cukup hakim harus menentukan peraturan hukum yang dapat diterapkan. Menyangkut tentang peraturan hukum yang dapat diterapkan untuk menyelesaikan sengketa oleh hakim, pada dasarnya menunjukkan bahwa sebelum menjatuhkkan suatu putusan hakim melakukan penelitian dalam rangka menemukan hukum (judge made lawa/rechtvinding). Dengan demikian hakim telah berusaha semaksimal mungkin untuk dapat menjatuhkan putusan yang obyektif, adil dan tidak dipengaruhi oleh unsur apapun pun kecuali sikap obyektivitas dan rasa keadilan itu semata (Harahap, 1997: 136).

Putusan hakim adalah suatu pernyataan yang oleh hakim, sebagai pejabat negara yang diberi wewenang untuk itu, diucapkan dipersidangan dan bertujuan untuk mengakhiri atau menyelesaikan suatu perkara atau sengketa para pihak. Selanjutnya Soedikno Mertokoesoemo menambahkan bahwa bukan hanya yang diucapkan saja yang disebut putusan, melainkan juga pernyataan yang dituangkan dalam bentuk tertulis dan kemudian diucapkan oleh hakim dipersidangan. Sebuah konsep putusan (tertulis) tidak mempunyai kekuatan sebagai putusan sebelum diucapkan dipersidangan oleh hakim. Putusan yang diucapkan dipersidangan (uitspraak) tidak boleh berbeda dengan tertulis (vonnis). Vonnis adalah putusan yang belum mempunyai kekuatan hukum yang pasti, sehingga masih tersedia upaya hukum biasa, sedangkan gewisjde adalah putusan yang sudah mempunyai kekuatan hukum yang pasti, sehingga hanya tersedia upaya hukum khusus (Mertokoesoemo, 1985: 172). Dalam kaitannya dengan hukum acara Pengadilan Tata Usaha Negara, putusan yang telah memperoleh kekuatan hukun tetap adalah: 1) Putusan pengadilan tingkat pertama (Peradilan Tata Usaha Negara) yang sudah tidak dapat dimintakan upaya banding. 2) Putusan pengadilan tinggi (Pengadilan Tinggi Tata Usaha Negara) yang tidak dimintakan kasasi. 3) Putusan Mahkamah Agung dalam tingkat kasasi.

Putusan pengadilan yang telah memperoleh kekuatan hukum tetap pada dasarnya memiliki upaya hukum adalah putusan pengadilan yang sudah tidak memiliki upaya hukum (banding dan kasasi), namun sebagaimana disebutkan diatas banding dan kasasi adalah upaya hukum biasa, disamping itu masih terdapat hukum istimewa atau upaya hukum luar biasa. Dengan demikian putusan pengadilan yang telah mempunyai kekuatan hukum tetap juga masih bisa dilawan dengan upaya hukum istimewa.

Yang dimaksud dengan eksekusi putusan pengadilan adalah pelaksanaan putusan pengadilan oleh atau dengan bantuan pihak luar dari para pihak. Bantuan pihak luar tersebut, lebih dikenal 
sebutan eksekusi riel dalam perkara perdata (Indroharto, :369), yang di PTUN tidak dikenal, karena PTUN hanya sekedar pengadilan administrasi, yang tidak mempunyai kewenangan dalam arti fisik, melainkan hanya kewenangan yang abstrak dalam bidang administrasi Pasal 65 undang-undang Nomor 5 Tahun 1986 jo Undang-undang Nomor 9 Tahun 2004 jo Undang-undang Nomor 51 Tahun 2009 tentang Peradilan Tata Usaha Negara jo Undang-undang Nomor 9 Tahun 2004 jo Undang-undang Nomor 51 Tahun 2009.

Dalam hal ini yang perlu diperhatikan adalah bunyi dan Pasal 115 Undang-undang Peradilan Tata Usaha Negara Nomor 5 Tahun1986 jo Undangundang nomor 9 Tahun 2004 jo Undangundang Nomor 51 Tahun 2009, yang menyatakan bahwa, Hanya putusan pengadilan yang telah memperoleh kekutan hukum tetap yang dapat dilaksanakan.

Hukum Eksekusi di PTUN berbeda dengan hukum eksekusi di peradilan perdata. Diperadilan perdata hukum eksekusi dilengkapi dengan sarana-sarana fisik, yaitu: Juru Sita, bantuan Alat Negara (Polisi) dan sebagainya, yang dapat memaksa secara fiksi agar pihak yang kalah mematuhi putusan pengadilan. Di PTUN hal itu tidak dimungkinkan, PTUN hanya dilengakapi sarana-sarana administrasi saja, sesuai dengan kewenangannya yang hanya mengadili dari segi legalitas administrasi (pengadilan administrasi) (Fachrudin, 2003: 269).

Eksekusi PTUN hanya dilakukan melalui pengiriman surat kepada instansi yang bersangkutan agar putusan pengadilan dipatuhi dilaksanakan. Kalau tidak diketahui/dilaksanakan dalam tenggang waktu tertentu Ketua PTUN menulis surat lagi kepada atasannya dan seterusnya, dengan harapan agar atasan tersebut memerintahkan instansi bawahannya mematuhi putusan tersebut. Di dalam Pasal 119 Undang-undang Nomor 5 Tahun 1986 jo Undang-undang Nomor 9 Tahun 2004 jo Undang-undang Nomor 51 Tahun 2009 disebutkan; Ketua
Pengadilan wajib mengawasi pelaksanaan putusan pengadilan yang telah memperoleh kekuatan hukum tetap.

$$
\text { Putusan Pengadilan yang }
$$

mempunyai kekuatan hukum tetap, haruslah dilaksanakan. Tatapi dalam kenyataannya tidak semudah dari aturan yang ada. Dalam peradilan Tata Usaha Negara beberapa hambatan pelaksanaan peradilan Tata Usaha Negara (Fachrudin, 2003: 269), yaitu: pertama, tidak ada lembaga eksekutorial, artinya hambatan pelaksanaan putusan Peradilan Tata Usaha Negara yakni tidak adanya lembaga eksekutorial khusus untuk melaksanakan Putusan Peradilan Tata Usaha Negara. Tidak adanya lembaga paksa agar Pejabat Tata Usaha Negara agar putusan dapat dilaksanakan.

Kedua, adalah rendahnya tingkat kesadaran pejabat Tata Usaha Negara dalam mentaati putusan pengadilan Tata Usaha Negara. Tidak adanya sanksi untuk membuat pejabat Tata Usaha Negara tidak merasa takut apabila ia tidak menjalankan putusan pengadilan itu. Adanya kepentingan pribadi pejabat eksistensi keputusan Tata Usaha Negara yang diterbitkannya dan lemahnya tingkat kesadaran hukum Badan atau Pejabat Tata Usaha Negara adalah sangat besar pengaruhnya terhadap dipatuhi atau tidaknya putusan Hakim Peradilan Tata Usaha Negara lebih menyandarkan pada kerelaan pejabat yang bersangkutan untuk melaksanaknnya (floating execution). Dengan hanya menyandarkan kerelaan, tentu banyak pejabat yang tidak rela bila harus memenuhi putusan, sehingga memilih untuk tidak memilih putusan.

Ketiga adalah tidak adanya peraturan yang tegas, artinya eksekusi putusan Peradilan Tata Usaha Negara telah dimuat undang-undang Nomor 5 Tahun 1986 jo Undang-undang Nomr 9 tahun 2004 jo Undang-undang Nomor 51 Tahun 2009, yang menyebutkan bahwa pengadilan dapat meminta atasan Tata Usaha Negara yang bersangkutan atau presiden untuk memaksa tergugat melksanakan putusan pengadilan. 
Keempat adalah otonomi daerah sebagai hambatan pelaksanaan putusan PTUN, Otonomi Daerah yang pada saat ini di Indonesia diatur dengan Undangundang Nomor 32 Tahun 2004 tentang Pemerintahan Daerah. Pelaksanaan otonomi daerah di Indonesia mempunyai arah dan tujuan sebagai berikut: a) Peningkatan Kesejahteraan Masyarakat: Peningkatan pelayanan kepada masyarakat dan Pemberdayaan dan peran serta masyarakat; b) Peningkatan Daya Saing Daerah: (1) Merupakan perwujudan dari demokrasi, keadilan dan pemerataan, (2)Wujud perhatian terhadap keanekaragaman dan kekhususan yang ada di Indonesia dan (3) Pemeliharaan hubungan harmonis antara Pemerintah Pusat dan Daerah Otonom serta antar daerah otonom dalam kerangka Negara Kesatuan Republik Indonesia. Apabila hal itu terjadi, tidak ada upaya lagi terhadap tergugat hal inilah yang disebut eksekusi mengapung (floating eksecution). Upaya lain yang dapat ditempuh adalah mengajukan gugatan pembayaran ganti rugi tersebut kepada PN.

\section{SIMPULAN}

$\begin{array}{rrr} & \text { Pelaksanaan } & \text { Putusan Mahkamah } \\ \text { Agung } & \text { Nomor } & \text { 248/K.TUN/2008 }\end{array}$ Pelaksanan eksekusi putusan tersebut tidak dapat dilakukan karena putusan tersebut non eksekutabel, tidak adanya lembaga eksekutorial. Eksekusi putusan pengadilan adalah pelaksanaan putusan pengadilan oleh atau dengan bantuan pihak luar dari para pihak. Bantuan pihak luar tersebut, lebih dikenal sebutan eksekusi riel dalam perkara perdata yang di PTUN tidak dikenal, karena PTUN hanya sekedar pengadilan administrasi, yang tidak mempunyai kewenangan dalam arti fisik, melainkan hanya kewenangan yang abstrak dalam bidang administrasi. Hambatan pelaksanaan Tidak Ada Lembaga Eksekutorial Hambatan pelaksanaan Putusan Peradilan Tata Usaha Negara yakni tidak adanya lembaga eksekutorial khusus untuk melaksanakan
Putusan Peradilan Tata Usaha Negara. Tidak adanya lembaga paksa agar Pejabat Tata Usaha Negara agar putusan dapat dilaksanakan. Tidak adanya peraturan yang tegas Eksekusi putusan Peradilan Tata Usaha Negara telah dimuat undangundang Nomor 5 Tahun 1986 jo Undangundang Nomr 9 tahun 2004 jo Undangundang Nomor 51 Tahun 2009, yang menyebutkan bahwa pengadilan dapat meminta atasan Tata Usaha Negara yang bersangkutan atau presiden untuk memaksa tergugat melaksanakan putusan pengadilan.

\section{DAFTAR PUSTAKA}

Abdullah, A., (1994), Hukum Acara Peradilan Tata Usaha Negara, Cetakan Ketiga, Jakarta: Raja Grafindo Persada

Ariyuda, G., (2004), Praktik Pemberian Hak Atas Tanah yang Berasal dari Tanah Hak Pengelolaan, Makalah Seminar, Fakultas Hukum Universitas Airlangga, Surabaya, 24 Juli 2004

Chomzah, A.A., (2002), Hukum Pertanahan, Jakarta: Prestasi Pustaka.

Djuita, R., (2011), Hak Pengelolaan (HPL) antara Regulasi dan Implementasi, Jurnal Pertanahan Volume 1, Nomor 1, Edisi November 2011, Pusat Penelitian dan Pengembangan Badan Pertanahan Nasioanal Republik Indonesia, Jakarta

Fachrudin, I., (2003), Konsekwensi Pengawasan Peradilan Administrasi Terhadap Tindakan Pemerintah, Disertasi Doktor Universitas Pajajaran Bandung.

Harahap, Z., (1997), Hukum Acara Peradilan Tata Usaha Negara, Edisi Revisi, Jakarta: Raja Grafindo Persada. , (2002), Hukum Acara Peradilan Tata Usaha Negara, Jakarta: Raja Grafindo.

Harsono, B., (2001), Hukum Agraria Indonesia (Himpunan Peraturan-Peraturan Hukum Tanah,), Djambatan, Jakarta.

(2003), Undang-undang Pokok Agraria Sejarah pembentukan undnagundang Pokok Agraria, Jakarta: Djambatan. , (2008), Hukum Agraria Indonesia Jilid 1, Jakarta: Jambatan.

Hasibuan, A.D., dan Ferry A.S., (2013), Faktor Penyebab Tidak Dilaksanakannya Putusan Pengadilan Tata Usaha Negara 
dan Upaya Penanggulangannya (Analisis Kasus Putusan PTUN Medan No: 17/G/200o/PTUN-MDN), Mercatoria, 6 (2): 133-144

Himpunan Peraturan Pengadaan Tanah Bagi Pembangunan Untuk Kepentingan Umum, Syafruddin Kalo, Sofmedia, Jakarta

http//wikipedia.org.wiki.pelindo

http://farahfitriani.wordpress.com/2011/10/ha mbatan-pelaksanaan-putusan-peradilantata-usaha-negara-yang-mengakibatkanhilangnya-wiabwa-pun

Hutagalung, A.S., dan Markus G., (2009), Kewenangan Pemerintah di Bidang Pertanahan, Jakarta: Rajawali Pers

Indroharto, (1993), Upaya Memahami Undangundang Tentang Peradilan Tata Usaha Negara, Jakarta: Sinar Harapan.

Ketetapan MPR RI Nomor I/MPR/20o1 tentang Pembaharuan Agraria dan Pengelolaan Sumber Daya Alam

Kitab Undang-undang Hukum Perdata

Koentjaraningrat, (1997), Metode-metode Penelitian Masyarakat, Jakarta: Gramedia Pustaka

Limbong, B., (2012), Hukum Agraria Nasional, Jakarta: Margaretha Pustaka.

Lubis, M.Y., dan Abdul R.L., (1961), Hukum Pendaftaran Tanah, Bandung: Mandar Maju.

Mahfud MD, (1998), Politik Hukum di Indonesia, Jakarta: $\mathrm{LP}_{3} \mathrm{ES}$.

Mertokoesoemo, S., (1985), Hukum Acara Perdata Indonesia, Yogyakarta: Liberty

Parlindungan, A.P., (1994), Kapita Selekta Hukum Agraria, Bandung: Alumni.

(2008), Hak Pengelolaan Menurut Sistem Undang-undang Pokok Agraria, Bandung: Mandar Maju. , (2008), Komentar Atas Undangundang Pokok Agraria, Bandung: Mandar Maju.

Penjelasan Peraturan Pemerintah Nomor 8 Tahun 1953 Tentang Penguasaan Tanahtanah Negara

Perangin, E., (1989), Hukum Agraria di Indonesia Suatu Telaah dari Sudut Pandang Praktisi Hukum, Jakarta: Rajawali.

Peraturan Bersama Menteri Dalam Negeri dan Menteri Perhubungan Nomor 191 Tahun 1969 Tentang Penyediaan dan Penggunaan Tanah Untuk Keperluan Pelabuhan
Peraturan Menteri Agraria Nomor 9 Tahun 1965 Tentang Pelaksanaan Konversi Hak Penguasaan Atas tanah Negara dan Ketentuan-ketentuan Tentang Kebijaksanaan Selanjutnya Tentang Pelaksanaan Konversi Hak Penguasaan Atas Tanah Negara dan Kebijaksanaan

Peraturan Menteri dalam Negeri Nomor 1 tahun 1977 Tata Cara Permohonan dan Penyelesaian Pemberian Hak Atas Bagian-bagianTanah Hak Pengelolaan Serta Pendaftarannya

Peraturan Menteri Negara Agraria/Kepala Badan Pertanahan Nasional Nomor 9 Tahun 1999 Tentang Tata Cara Pemberian dan pembatalan Hak atas tanah Negara dan Hak Pengelolaan

Peraturan Pemerintah Nomor 10 Tahun 1961 Tentang Pendaftaran Tanah

Peraturan Pemerintah Nomor 24 Tahun 1997 Tentang Pendaftaran Tanah

Prodjohamidjojo, M., (1993), Hukum Acara Pengadilan Tata Usaha Negara, Jakarta: Ghalia Indonesia.

Raharjo, S., (2010), Teori Hukum (Strategi tertib manusia Lintas Ruang dan Generasi, Jakarta: Genta Publishing.

Reglemen Indonesia yang diperabharui (Het Herzeine Indonesisch Rgelement), S.194144

Salman, O., (2007), Teori Hukum (Mengingat, Mengumpulkan dan Membuka Kembali), Jakarta: Refika Aditama

Santoso, U., (2012), Hukum Agraria Kajian Komprehensif, Jakarta: Kencana Prenada Media Grup

Setiadi, W., (1994), Hukum Acara Pengadilan Tata Usaha Negara Suatu Perbandingan, Jakarta: PT Raja Grafindo Persada.

Siahaan, L.O., (2005), Prospek PTUN Sebagai Pranata Penyelesaian Sengketa Administrasi Di Indonesia, Jakarta: Perum Percetakan Negara Republik Indonesia.

Sihombing, I.E., (2009), Segi-segi Hukum Tanah Nasional Dalam Pengadaan Tanah Untuk Pembangunan, Jakarta: Universitas Trisakti.

Sjachran, B., (1992), Perlindungan Hukum Terhadap Sikap Tindak Administrasi Negara, Bandung: Alumni.

Soekanto, S., (1986), Pengantar Penelitian Hukum, Jakarta: UI Press 
Soekanto, S., dan Sri M, (2001), Penelitian Hukum Normatif, Jakarta: Radja Grafindo Persada

Soemaryono dan Anna E., Tuntutan Praktek Beracara di Pengadilan Tata Usaha Negara, Jakarta, Prima Media Pustaka Gramedia Majalah, Jakarta, hlm 129

Sumardjono, M.S.W., (2008), Tanah dalam Prespektif Hak Ekonomi Sosial dan Budaya, Jakarta: Kompas.

Sunggono, B., (2012), Metode Penelitian Hukum, Depok: Raja Garfindo Persada.

Supomo, R., (1971), Hukum Acara Perdata Pengadilan, Cetakan 5, Jakarta: Pardnya Paramita.

Suryabrata, S., (1998), Metodelogi Penelitian, Jakarta: Raja Grafindo Persada.

Syarief, E., (2012), Menuntaskan Sengketa Tanah Melalui Pengadilan Khusus Pertanahan, Kepustakaan Populer Gramedia, Jakarta
Undang-undang Pengadilan Tata Usaha Negara Nomor 5 Tahun 1986

Undang-undang Pengadilan Tata Usaha Negara Nomor 51 Tahun 2009

Undang-undang Pengadilan Tata Usaha Negara Nomor 9 Tahun 2004

Undang-undang Pokok Agraria Nomor 5 tahun 1960

Undang-undang Rumah Susun Nomor 16 Tahun 1985

Widodo, W., (1993), Eksistensi dan Kedudukan Hak Pengelolaan Dalam Hukum Tanah Indonesia, Jurnal Mimbar Hukum, Nomor 18/X/93, Fakultas Hukum Universitas Gadja Mada, Yogyagarta, 1993

Zein, R., (1995), Hak Pengelolaan dalam Sistem Undang-undang Pokok Agraria, Jakarta: Rineka Cipta. 